Research Article

Genomics and Bioinformatics

\title{
Molecular relationships of Campomanesia xanthocarpa within Myrtaceae based on the complete plastome sequence and on the plastid ycf2 gene
}

\author{
Lilian de Oliveira Machado ${ }^{1}$ (iD, Leila do Nascimento Vieira ${ }^{2}$ (id, Valdir Marcos Stefenon ${ }^{1,3}$, Helisson \\ Faoro $^{4}$, Fábio de Oliveira Pedrosa ${ }^{2}$, Miguel Pedro Guerra ${ }^{1}$ and Rubens Onofre Nodari ${ }^{1}$ in \\ ${ }^{1}$ Universidade Federal de Santa Catarina, Centro de Ciências Agrárias, Departamento de Fitotecnia, \\ Florianópolis, SC, Brazil. \\ ${ }^{2}$ Universidade Federal do Paraná, Centro Politécnico, Curitiba, PR, Brazil. \\ ${ }^{3}$ Universidade Federal do Pampa, Campus São Gabriel, São Gabriel, RS, Brazil. \\ ${ }^{4}$ Fundação Oswaldo Cruz, Instituto Carlos Chagas, Curitiba, PR, Brazil.
}

\begin{abstract}
Plastomes are very informative structures for comparative phylogenetic and evolutionary analyses. We sequenced and analyzed the complete plastome of Campomanesia xanthocarpa and compared its gene order, structure, and evolutionary characteristics within Myrtaceae. Analyzing 48 species of Myrtaceae, we identified six genes representing 'hotspots' of variability within the plastomes (ycf2, atpA, rpoC2, $p c b E, n d h H$ and rps 16), and performed phylogenetic analyses based on: (i) the ycf2 gene, (ii) all the six genes identified as 'hotspots' of variability, and (iii) the genes identified as 'hotspots' of variability, except the ycf2 gene. The structure, gene order, and gene content of the C. xanthocarpa plastome are similar to other Myrtaceae species. Phylogenetic analyses revealed the $y c f 2$ gene as a promissing region for barcoding within this family, having also a robust phylogenetic signal. The synonymous and nonsynonymous substitution rates and the $K a / K s$ ratio revealed low values for the $y c f 2$ gene among $C$. xanthocarpa and the other 47 analyzed species of Myrtaceae, with moderate purifying selection acting on this gene. The average nucleotide identity (ANI) analysis of the whole plastomes produced phylogenetic trees supporting the monophyly of three Myrtaceae tribes. The findings of this study provide support for planning conservation, breeding, and biotechnological programs for this species.
\end{abstract}

Keywords: Myrteae, guabiroba, plastid, ycf2, evolution.

Received: January 16, 2019; Accepted: July 24, 2019.

\section{Introduction}

Plastidial genomes (plastomes) are useful tools to perform comparative analyses associated with phylogenetic and evolutionary studies. The relatively small size, mostly uniparental inheritance, high gene synteny, and elevated copy number in green plant cells are the main characteristics that make plastids useful for such studies. In seed plants, plastome sizes range from 70 to $218 \mathrm{Kbp}$ (Xiao-Ming et al., 2017) and typically present a quadripartite structure with two inverted repeat regions (IRs) divided between the large (LSC) and the small (SSC) single-copy regions (Bock, 2007).

The plastome contains essential genes in conserved open reading frames (ORFs). However, some plastidial ORFs have unknown function and are called hypothetical chloroplast open reading frame $(y c f)$. The largest plastome coding sequence (ORF2280 or $y c f 2$ ) encodes a plastidial protein (Glick and Sears, 1993) whose function has been hypothesized to exhibit similarities with $f_{s t H}$, such as

Send correspondence to Rubens Onofre Nodari. Universidade Federal de Santa Catarina, Centro de Ciências Agrárias, Departamento de Fitotecnia, Rod. Admar Gonzaga, 1346, 88034-001 Florianópolis, SC, Brazil. E-mail: rubens.nodari@ufsc.br.
ATPase-related activities, chaperone function, and activity associated with cell division (Wolfe, 1994).

The elevated substitution rates of the $y c f 2$ gene led to a pseudogenization process (Downie et al., 1994; Oliver et al., 2010; Wolf et al., 2011). This gene is absent in some plastomes (Downie et al., 1994; Millen et al., 2001), especially in monocot grasses, such as maize, rice, and sugarcane (Maier et al., 1995; Matsuoka et al., 2002; Asano et al., 2004). Thus, the high variability of $y c f 2$ makes it a potential candidate for species-level DNA barcoding (Kumar et al., 2009).

Investigating the sequence variation and phylogenetic characteristics of the $y c f 2$ gene in angiosperms, Huang et al. (2010) showed that it provides generally well-supported phylogenies, consistent with those inferred from the most comprehensive multigene data. Within angiosperms, Myrtaceae is a large family of shrubs and trees with well-known ecological and economic importance in tropical and subtropical regions of the globe. According to The Plant list (2013), this family is composed by 144 genera and 5,970 species distributed across the world, with predominantly Neotropical and Southern Hemisphere distribution. Its main center of di- 
versity is the wet tropics, predominantly in South America, Australia, and tropical Asia (Grattapaglia et al., 2012). Evolutionary and phylogenetic trends within this family have been studied using single and combined plastidial genes, as well as by complete plastome sequencing (Steane, 2005; Bayly et al., 2013, 2016; Jo et al., 2016; Eguiluz et al., 2017; Machado et al., 2017).

Campomanesia xanthocarpa Berg. is a fruit tree species of the family Myrtaceae, native to South America, occurring in Brazil, Argentina, Uruguay, and Paraguay (Lorenzi, 1992). In addition to feeding several mammal and bird species, its fruits are appreciated by local people, being consumed fresh and as component of cakes, ice cream, and beverages. As a heliophyte species, C. xanthocarpa is indicated for recovery of degraded areas and as an ornamental plant (Souza and Lorenzi, 2005). Controlled studies have shown that extracts of $C$. xanthocarpa leaves induced reduction in weight gain and glycemia in rats (Biavatti et al., 2004) and were efficient in avoiding gastric ulceration (Markman et al., 2004). In hypercholesterolemic human patients, encapsulated dried leaves of C.xanthocarpa significantly decreased total cholesterol and LDL levels (Klafke et al., 2010). This plant also demonstrated anti-inflammatory (Klafke et al., 2016), antimicrobial (Capeletto et al., 2016) and anti-oxidant (Viecili et al., 2014) activities, and may also have therapeutic applications during pregnancy, reducing reabsorption sites, increasing placenta weight and the number of live fetuses (Auharek et al., 2013).

In an effort to elucidate the evolutionary history of South American tree species, the plastome of different native species has been sequenced (Vieira et al., 2014b, 2016a,b; Lopes et al., 2018a,b), including species from the Myrtaceae family (Machado et al., 2017). Aiming to contribute to this attempt and to generate useful information for future efforts towards biotechnology, breeding, and genetic conservation of $C$. xanthocarpa, we used a next-generation sequencing technology to sequence the complete plastome of this species and describe here its genome structure and gene content. Considering previous studies on plastidial genomes, suggesting strong signatures of positive selection between close-related species of tribe Myrteae, this study aimed to answer three main questions: (i) Does the C. xanthocarpa plastome resemble the plastidial structure of the species from the tribe Myrteae and family Myrtaceae? (ii) Does the $C$. xanthocarpa $y c f 2$ gene present signatures of positive selection within the tribe Myrteae and family Myrtaceae? (iii) Does the $y c f 2$ gene have a strong taxonomic/phylogenetic signal for resolving relationships within the tribe Myrteae and family Myrtaceae compatible to classic plastidial phylogenies?

\section{Material and Methods}

\section{Plant material and plastidial DNA isolation}

For plastidial DNA isolation, fresh leaves were collected from a single individual of $C$. xanthocarpa in the Department of Botany, Federal University of Santa Catarina
(UFSC), Brazil $\left(27^{\circ} 36.094^{\prime \prime} \mathrm{S}, 48^{\circ} 31.310^{\prime \prime} \mathrm{W}\right)$. The plastidial DNA was obtained according to Vieira et al. (2014a), with the modification that plastidial lysis was achieved by incubating the chloroplast pellet with $8 \mathrm{~mL}$ of DNA isolation buffer [1.5 mL 20\% SDS, $450 \mu \mathrm{L}$ 2-mercaptoethanol, and 50 $\mu \mathrm{L}$ proteinase $\mathrm{K}(10 \mathrm{mg} / \mathrm{mL})]$ in a centrifuge tube at $55^{\circ} \mathrm{C}$ for $4 \mathrm{~h}$ or overnight.

\section{Plastome assembly and annotation}

The sequencing libraries were prepared using $1 \mathrm{ng}$ of plastidial DNA with the Nextera XT DNA Sample Prep Kit (Illumina Inc., San Diego, CA), according to the manufacturer's instructions. Libraries were sequenced using the MiSeq Reagent Kit v3 (600 cycles) on an Illumina MiSeq Sequencer (Illumina Inc., San Diego, California, USA). The obtained paired-end reads $(2 \times 300 \mathrm{bp})$ were used for de novo assembly performed with CLC Genomics Workbench v8.0.1. The same software was used to estimate plastome coverage. Initial annotation of the $C$. xanthocarpa plastome was performed using DOGMA - Dual Organellar GenoMe Annotator (Wyman et al., 2004). From this initial annotation, putative start, stop, and intron positions were determined based on comparisons to homologous genes in other plastomes. The tRNA genes were further verified using tRNAscan-SE (Schattner et al., 2005). A circular plastome map was drawn using OGDRAW - OrganellarGenomeDRAW (Lohse et al., 2007). REPuter (Kurtz and Schleiermacher, 1999) was used to identify and locate the IRs in the C. xanthocarpa plastome by forward versus reverse complement (palindromic) alignment, with minimal repeat size was set to $30 \mathrm{bp}$, and identity of repeats $\geq 90 \%$. REPuter was also used to identify and locate LSC/IRb/SSC/IRa sizes and boundaries in 12 other previously published chloroplast genomes.

The complete $C$. xanthocarpa plastome sequence reported in this study was deposited in the GenBank database under accession number KY392760.

\section{Taxonomical relationships within Myrtaceae based on the whole plastome}

Aiming to investigate the taxonomical relationships within Myrtaceae based on the whole plastome sequences, we employed the average nucleotide identity (ANI) analysis. This analysis is a measure of nucleotide-level genomic similarity between two genomes, where the averages reflect the degree of divergence between coding regions of the compared genomes and, consequently, evolutionary distances between these genomes. It consists in calculating the percentage nucleotide identity of the matching regions of two genomes, as an average for all matching regions.

Sequences from plastomes of 47 Myrtaceae species including the C. xanthocarpa plastome reported in the present study and 46 Myrtaceae species, which have whole plastome sequences deposited in the GenBank database, were used in this analysis, including 30 species of genus Eucalyptus, six of the genus Corymbia, two of the genus Angophora, and one each of the Allosyncarpia, Eugenia, Stockwellia, 
Syzygium, Acca, Pimenta, Plinia and Psidium genera (Table 1). The plastome sequence of Lagerstroemia fauriei (Myrtales: Lythraceae) was used as outgroup.

ANI was calculated for the whole plastomes using the Pyani script (Python module) for average nucleotide identity analyses; (https://github.com/widdowquinn/pyani), aligning the sequences with the MUMmer algorithm (Goris et al., 2007).

\section{Evolutionary and phylogenetic patterns within Myrtaceae based on the ycf2 gene}

In order to evaluate the phylogenetic signal of the $y c f 2$ gene within Myrtaceae, we analyzed evolutionary and phylogenetic patterns of this gene among representatives of this family using sequences obtained from the same species employed in the ANI analysis (Table 1).

The evolutionary patterns of the plastidial $y c f 2$ gene in family Myrtaceae were evaluated by estimating the $K a / K s$ ratio for the $y c f 2$ protein-coding gene. The evolutionary characteristics, nonsynonymous $(K a)$ and synonymous substitution rates $(K s)$, as well as $K a / K s$ ratio, were calculated using Model Averaging in the KaKs_Calculator program (Zhang et al., 2006). The genes were pairwise aligned using the MUltiple Sequence Comparison by Log-Expectation (MUSCLE) algorithm (Edgar, 2004) to identify synonymous and nonsynonymous substitution.

For the phylogenetic relationships of Myrtaceae based on the $y c f 2$ gene, sequences were aligned by Multiple Alignment using Fast Fourier Transform -MAFFT (Katoh and Standley, 2013). The substitution model was selected by means of the Akaike information criterion using jModelTest (Darriba et al., 2012) with seven substitution schemes, as this set covers all the possible models present in MrBayes software. Bayesian inference was conducted using MrBayes v3.2.6 at CIPRES Science Gateway V. 3.3, with the general time reversible (GTR) model of substitution incorporating invariant sites (GTR $+\mathrm{I})$, as suggested by the model test selection. Markov Chain Monte Carlo (MCMC) simulations were run for 6,000,000 generations (average standard deviation of split frequencies $=0.003027$ ), discarding the first $25 \%$ of trees as burn-in. The remaining trees were represented and edited using FigTree v1.4.1.

In addition, we performed a sliding window analysis of the total plastid genome of all analyzed species using the software DNAsp v.5 (Librado and Rozas, 2009). The window length and the step size were set as 200 and $50 \mathrm{bp}$, respectively. The genes representing hotspots of sequence divergence were identified and used for a new phylogenetic analysis, both including and excluding the $y c f 2$ region, in order to evaluate the individual contribution of this gene to the phylogenetic patterns in comparison to other plastid genes highly variable within Myrtaceae.

\section{Results}

\section{Sequencing results}

The Illumina MiSeq sequencing resulted in a high plastome coverage $(\sim 370 \mathrm{x})$ with a total of $3,240,548$ raw reads, an average read length of $147.9 \mathrm{bp}$, and a total number of $479,391,832$ base pairs. After trimming (quality score limit of 0.05 ) a total of $3,228,689$ reads were mapped in aligned pairs with mean length of $147.52 \mathrm{bp}$, generating a total of 58,815,423 bp, which were used for the de novo assembly.

\section{General features of the Campomanesia xanthocarpa plastome}

The C. xanthocarpa plastome has $158,131 \mathrm{bp}$ in length, with a GC content of $36.98 \%$ and the general quadripartite structure, consisting of a pair of IRs $(25,970 \mathrm{bp})$ separated by the LSC $(87,596 \mathrm{bp})$ and SSC $(18,595 \mathrm{bp})$ regions (Figure 1; Table 2). It is the smallest plastidial genome size within the reported plastomes of Myrtaceae, 2,582 bp shorter than the plastome of Corymbia gummifera, the longest plastidial genome reported for this family. The IR region of the C. xanthocarpa plastome is the shortest among the 48 Myrtaceae species evaluated herein (Table 2).

The plastome contains 112 genes and four pseudogenes, with the same gene order and gene clusters as other Myrtaceae. The presence of pseudogenes is a known feature of Myrtaceae plastomes. Out of the 112 genes, 90 were single copy and 19 were duplicated (Figure 1; Table S1). In addition, 18 were intron-containing genes (Table 3 ), including nine protein-coding genes with a single intron, two protein-coding genes with a double intron, six tRNA genes with a single intron and one trans-splicing gene (rps12). Among intron-containing genes, 12 are located in the LSC region, one in the $\mathrm{SSC}$ region, and four in the IR region.

The $\mathrm{LSC} / \mathrm{IRb} / \mathrm{SSC} / \mathrm{IRa}$ boundary regions were examined to compare four junctions (JLA, JLB, JSA, and JSB) among 12 species of three tribes of Myrtaceae and an outgroup, from Lythraceae family. The IR lengths ranged from $25,792 \mathrm{bp}$ to $26,414 \mathrm{bp}$, and the position of IRs boundaries varied for each species. The boundary between LSC and IR regions was located within the rps 19 gene, resulting in the formation of an rps 19 pseudogene in C. xanthocarpa, A. ternata, S. quadrifida, $P$. dioica, $P$. trunciflora, $P$. guaja$v a$ and $L$. fauriei chloroplast genomes (Figure S1). In the other six species, the LSC comprises an intact $r p s 19$ gene together with 2 bp (E. grandis), 3 bp (A. sellowiana and $E$. uniflora), 6 bp (S. cumini), and 8 bp (A. costata and $C$. maculata) of non-coding region beyond the LSC-IRb border. The IRa-LSC border in these six species is located in the intergenic spacer (IGS) between $r p l 2$ and $t r n H$. The $t r n H$ gene in C. xanthocarpa, A. ternata, S. quadrifida, P. dioica, $P$. trunciflora, $P$. guajava and $L$. fauriei extends to the IRa by $31 \mathrm{bp}, 5 \mathrm{bp}, 5 \mathrm{bp}, 1 \mathrm{bp}, 4 \mathrm{bp}, 11 \mathrm{bp}$ and $3 \mathrm{bp}$, respectively, whereas the same gene for A. sellowiana, E. uniflora, $A$. costata and C. maculata, E. grandis, and $S$. cumini is, respectively $53 \mathrm{bp}, 44 \mathrm{bp}, 9 \mathrm{bp}, 9 \mathrm{bp}, 2 \mathrm{bp}$, and $56 \mathrm{bp}$ away from the 
Table 1 - Comparison of chloroplast genomes of Myrtaceae species and outgroup analyzed in this study.

\begin{tabular}{|c|c|c|c|c|c|}
\hline Species & Accession & Size & $\mathrm{LSC}^{\mathrm{b}}$ & $\mathrm{SSC}^{\mathrm{c}}$ & $\mathrm{IR}^{\mathrm{d}}$ \\
\hline Campomanesia xanthocarpa ${ }^{\text {a }}$ & KY392760 & 158,131 & 87,596 & 18,595 & 25,970 \\
\hline Acca sellowiana & KX289887 & 159,370 & 88,028 & 18,598 & 26,372 \\
\hline Allosyncarpia ternate & KC180806 & 159,593 & 88,218 & 18,571 & 26,402 \\
\hline Angophora costata & KC180805 & 160,326 & 88,769 & 18,773 & 26,392 \\
\hline Angophora floribunda & KC180804 & 160,245 & 88,715 & 18,746 & 26,392 \\
\hline Corymbia eximia & KC180802 & 160,012 & 88,522 & 18,672 & 26,409 \\
\hline Corymbia gummifera & KC180800 & 160,713 & 88,310 & 17,197 & 27,603 \\
\hline Corymbia henryi & KP015032 & 160,095 & 88,589 & 18,688 & 26,409 \\
\hline Corymbia maculate & KC180801 & 160,045 & 88,557 & 18,670 & 26,409 \\
\hline Corymbia tessellaris & KC180803 & 160,127 & 88,617 & 18,692 & 26,409 \\
\hline Corymbia torelliana & KP015033 & 159,994 & 88,494 & 18,682 & 26,409 \\
\hline Eucalyptus aromaphloia & KC180789 & 160,149 & 88,925 & 18,468 & 26,378 \\
\hline Eucalyptus baxteri & KC180773 & 160,032 & 88,926 & 18,368 & 26,369 \\
\hline Eucalyptus camaldulensis & KC180791 & 160,164 & 88,874 & 18,492 & 26,399 \\
\hline Eucalyptus cladocalyx & KC180786 & 160,213 & 89,045 & 18,376 & 26,396 \\
\hline Eucalyptus cloeziana & KC180779 & 160,015 & 88,867 & 18,446 & 26,351 \\
\hline Eucalyptus curtisii & KC180782 & 160,038 & 88,828 & 18,448 & 26,381 \\
\hline Eucalyptus deglupta & KC180792 & 160,177 & 88,936 & 18,425 & 26,408 \\
\hline Eucalyptus delegatensis & KC180771 & 159,724 & 88,490 & 18,498 & 26,368 \\
\hline Eucalyptus diversicolor & KC180795 & 160,214 & 88,994 & 18,416 & 26,402 \\
\hline Eucalyptus diversifolia & KC180774 & 159,954 & 88,901 & 18,315 & 26,369 \\
\hline Eucalyptus elata & $\mathrm{KC} 180776$ & 159,899 & 88,762 & 18,401 & 26,368 \\
\hline Eucalyptus erythrocorys & KC180799 & 159,742 & 88,691 & 18,287 & 26,382 \\
\hline Eucalyptus globulus & AY780259 & 160,286 & 89,012 & 18,488 & 26,393 \\
\hline Eucalyptus grandis & HM347959 & 160,137 & 88,872 & 18,475 & 26,395 \\
\hline Eucalyptus guilfoylei & KC180798 & 160,520 & 89,054 & 18,096 & 26,685 \\
\hline Eucalyptus marginata & $\mathrm{KC} 180781$ & 160,076 & 88,828 & 18,476 & 26,386 \\
\hline Eucalyptus melliodora & KC180784 & 160,386 & 89,073 & 18,557 & 26,378 \\
\hline Eucalyptus microcorys & KC180797 & 160,225 & 89,051 & 18,410 & 26,382 \\
\hline Eucalyptus nitens & KC180788 & 160,271 & 89,005 & 18,468 & 26,399 \\
\hline Eucalyptus obliqua & KC180769 & 159,527 & 88,293 & 18,498 & 26,368 \\
\hline Eucalyptus patens & KC180780 & 160,187 & 88,902 & 18,543 & 26,371 \\
\hline Eucalyptus polybractea & KC180785 & 160,268 & 88,944 & 18,530 & 26,397 \\
\hline Eucalyptus radiate & KC180770 & 159,529 & 88,295 & 18,498 & 26,368 \\
\hline Eucalyptus regnans & KC180777 & 160,031 & 88,860 & 18,447 & 26,362 \\
\hline Eucalyptus saligna & KC180790 & 160,015 & 89,041 & 18,426 & 26,274 \\
\hline Eucalyptus salmonophloia & KC180796 & 160,413 & 89,173 & 18,466 & 26,387 \\
\hline Eucalyptus sieberi & KC180775 & 159,985 & 88,848 & 18,401 & 26,368 \\
\hline Eucalyptus spathulata & KC180793 & 161,071 & 88,729 & 17,116 & 27,613 \\
\hline Eucalyptus torquata & KC180794 & 160,223 & 89,018 & 18,439 & 26,383 \\
\hline Eucalyptus umbra & KC180778 & 159,576 & 88,864 & 18,658 & 26,027 \\
\hline Eucalyptus verrucata & $\mathrm{KC} 180772$ & 160,109 & 88,890 & 18,481 & 26,369 \\
\hline Eugenia uniflora & KR867678 & 158,445 & 87,459 & 18,318 & 26,334 \\
\hline Pimenta dioica & KY085891 & 158,984 & 87,572 & 18,586 & 26,413 \\
\hline Plinia trunciflora & KU318111 & 159,512 & 88,097 & 18,587 & 26,414 \\
\hline Psidium guajava & KX364403 & 158,841 & 87,675 & 18,464 & 26,351 \\
\hline Stockwellia quadrifida & $\mathrm{KC} 180807$ & 159,561 & 88,247 & 18,544 & 26,385 \\
\hline Syzygium cumini & GQ870669 & 160,373 & 89,081 & 18,508 & 26,392 \\
\hline Lagerstroemia fauriei (Lythraceae) ${ }^{\mathrm{e}}$ & KT358807 & 152,440 & 83,923 & 16,933 & 25,792 \\
\hline
\end{tabular}

${ }^{\mathrm{a}}$ Species with plastid genomes sequenced in this study; ${ }^{\mathrm{b}}$ Large Single Copy Region; ${ }^{\mathrm{c}}$ Small Single Copy Region; ${ }^{\mathrm{d}}$ Inverted Repeat Region; ${ }^{\mathrm{e}}$ Outgroup 




Figure 1 - Gene map of the Campomanesia xanthocarpa chloroplast genome. Genes drawn inside the circle are transcribed clockwise, and genes drawn outside are transcribed counterclockwise. Genes belonging to different functional groups are color-coded. The darker gray in the inner circle corresponds to GC content, and the lighter gray corresponds to AT content.

IRa-LSC border. The boundary of the SSC-IRb junction in Myrtales plastomes was located within the $y c f 1$ gene, also resulting in the formation of a $\psi$ ycfl pseudogene, which varied in length between $1,007 \mathrm{bp}$ and $2,251 \mathrm{bp}$. In the $A$. ternata and L. fauriei chloroplast genomes, the $n d h F$ gene at the IRb-SSC border extends $35 \mathrm{bp}$ and 38 bp into the IRb region, respectively. This gene is located in the SSC region in the 11 other species, and is separated from the IRb-SSC border by five to $225 \mathrm{bp}$.

\section{Taxonomic relationships within Myrtaceae based on} the whole plastome

The average nucleotide identity (ANI) analysis represents a mean of identity values between homologous regions 
Table 2 - Summary of Campomanesia xanthocarpa chloroplast genome characteristics.

\begin{tabular}{lc}
\hline Characteristics of plastome & C. xanthocarpa \\
\hline Plastome Size (bp) & 158,131 \\
LSC size in bp (\%) & $87,596(55.39)$ \\
SSC size in bp (\%) & $18,595(11.76)$ \\
IR length in bp & 25,970 \\
Different genes & 115 \\
Different PCG & 77 \\
Different tRNA genes & 30 \\
Different rRNA genes & 4 \\
Different pseudogenes & 4 \\
Different genes duplicated by IR & 20 \\
Different genes with introns & 18 \\
Overall \% GC content & 36.98 \\
\% GC content in LSC & 34.8 \\
\% GC content in SSC & 30.6 \\
\% GC content in IR & 42.9 \\
\hline
\end{tabular}

$\mathrm{PCG}=$ Protein-coding gene

Table 3 - Genes with introns in Campomanesia xanthocarpa chloroplast genome and length of exons and introns.

\begin{tabular}{|c|c|c|c|c|c|c|}
\hline Region & Gene & $\begin{array}{l}\text { Exon I } \\
\text { (bp) }\end{array}$ & $\begin{array}{l}\text { Intron I } \\
\text { (bp) }\end{array}$ & $\begin{array}{l}\text { Exon II } \\
\text { (bp) }\end{array}$ & $\begin{array}{c}\text { Intron II } \\
\text { (bp) }\end{array}$ & $\begin{array}{c}\text { Exon III } \\
\text { (bp) }\end{array}$ \\
\hline LSC & rps16 & 206 & 889 & 38 & & \\
\hline LSC & rpoCl & 1616 & 730 & 452 & & \\
\hline LSC & atpF & 410 & 747 & 146 & & \\
\hline LSC & $\operatorname{pet} B$ & 5 & 772 & 647 & & \\
\hline LSC & $\operatorname{pet} D$ & 8 & 753 & 473 & & \\
\hline LSC & rpl16 & 398 & 1005 & 8 & & \\
\hline LSC & $y c f 3$ & 152 & 725 & 227 & 760 & 125 \\
\hline LSC & clpP & 227 & 620 & 290 & 871 & 68 \\
\hline LSC & $\operatorname{trnK}-U U U$ & 34 & 2530 & 36 & & \\
\hline LSC & $\operatorname{trn} G-U C C$ & 22 & 750 & 48 & & \\
\hline LSC & $\operatorname{trn} V-U A C$ & 36 & 595 & 38 & & \\
\hline LSC & $\operatorname{trnL} L-U A A$ & 36 & 504 & 49 & & \\
\hline $\mathrm{SSC}$ & $n d h A$ & 539 & 1061 & 551 & & \\
\hline LSC/IRs & $\operatorname{rps} 12 *$ & 113 & - & 209 & - & 26 \\
\hline IR & $r p l 2$ & 434 & 662 & 392 & & \\
\hline IR & $n d h B$ & 755 & 695 & 776 & & \\
\hline IR & $\operatorname{trnI}-G A U$ & 36 & 956 & 33 & & \\
\hline IR & $\operatorname{trn} A-U G C$ & 37 & 804 & 34 & & \\
\hline
\end{tabular}

*rps12 is trans-spliced with the 5 '-end located in the LSC region and the duplicated 3 '-end in the IR regions

shared by two genomes, and was used to compare the complete plastomes of 47 species of Myrtaceae and Lagerstroemia fauriei as outgroup species. The plastomes sequence analysis $(\sim 160 \mathrm{~kb})$ indicated an ANI above the $95 \%$ threshold for all species within Myrtaceae. Despite the high overall ANI value observed, two major clades can be identified in the dendrogram and are closely apportioned in the heatmap (Figure 2). The Myrteae clade consists of six species [Campomanesia $+[[$ Acca + Psidium $]+[[$ Pimenta + Plinia $]+$ Eugenia]]]. The second clade, which includes species from both tribes Syzygieae and Eucalypteae, is subdivided in four subgroups, one containing all Eucalyptus species (all pairwise comparisons with ANI values near 100\%), a second with representatives of Stockwellia and Allosyncarpia, a third subgroup comprising Corymbia and Angophora, and a fourth subgroup with the unique Sysygium species, from tribe Syzygieae (Figure 2).

\section{Evolutionary and phylogenetic patterns within Myrtaceae based on the ycf2 gene}

The translated product of $y c f 2$ from the plastome of $C$. xanthocarpa contains 2,295 amino acids $(6,885 \mathrm{bp})$. It is longer than the sequence reported from all other species of Myrtaceae included in this study (ranging from 2,288 to 2,289 amino acids), except for Eucalyptus spathulata. This difference is observed in the $\mathrm{C}$-terminal portion of the translated product (Figure 3). The translated product of this gene in C. xanthocarpa has the same amino acid sequence as the other species up to position 2,283 (Figure 3). The amino acids from position 2,284 to 2,288 are conserved in all other species, with exception of $E$. spathulata. The amino acids of positions 2,289 and 2,290 in P. guajava and from positions 2,289 to 2,295 in E. spathulata are different from the amino acids of C. xanthocarpa (Figure 3). The analysis of the pairwise diversity between C. xanthocarpa and 46 species of Myrtaceae (Table 4) showed a $\mathrm{Ka}$ ranging from 0.0019 (Pimenta dioica) to 0.0054 (Eucalyptus grandis, E. deglupta and Corymbia gummifera) with a mean $K a=0.0048$. Estimations of Ks ranged from 0.0010 (Acca sellowiana and Plinia trunciflora) to 0.0138 (Eucalyptus erythrocorys), with a mean $K s=0.0114$. The average $K a / K s$ ratio was 0.4620 , ranging from 0.03207 (Stockwellia quadrifida) to 3.0 (Plinia trunciflora).

The matrix of the $y c f 2$ gene used for the phylogenetic inference was composed of 6,969 nucleotide positions, and the Bayesian phylogenetic tree with highest log-likelihood $(\operatorname{lnL}=-11,575.58)$ is shown in Figure 4. Monophyly of the tribes of Myrteae and Eucalypteae was confirmed with posterior probability (PP) of 1.0 (Figure 4). The tribe Syzygieae is sister to Eucalypteae with $\mathrm{PP}=1.0$.

The clades within the Myrteae tribe were highly supported, with posterior probability of 0.9788 for the clade Eugenia uniflora, Acca sellowiana, Campomanesia xanthocarpa, Pimenta dioica, Plinia trunciflora, and Psidium guajava, and PP $=1.0$ for the node that ties $A$. sellowiana and $C$. xanthocarpa. Similarly, the Eucalypteae tribe segregated into two well-supported monophyletic clades: [Eucalyptus $[$ Angophora + Corymbia $](\mathrm{PP}=1.0)$ and $[$ Allosyncarpia ternata + Stockwelia quadrifida $](\mathrm{PP}=1.0)$.

The sliding window analysis (Figure 5 ) revealed six genes as hotspots of sequence divergence $(\pi 30.03)$ : $y c f 2$, atp $A, r p o C 2, p c b E, n d h H$, and rps 16 . The phylogenetic tree constructed with all six genes (Figure S2) revealed the same topology obtained in the tree built only with the $y c f 2$ gene se- 


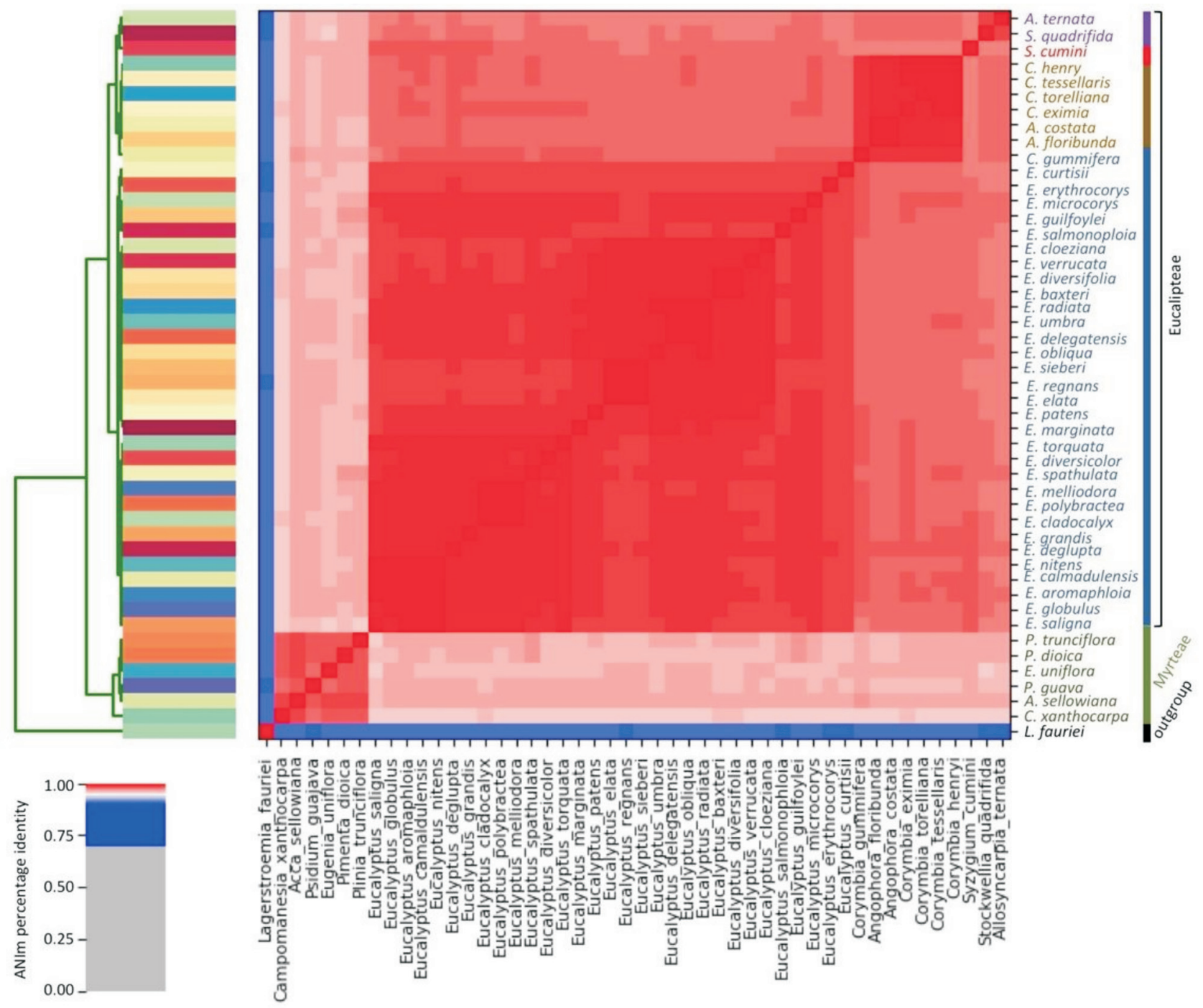

Figure 2 - Heatmap of ANIm percentage identity for 48 Myrtaceae species and the outgroup species Lagerstroemia fauriei (Myrtales: Lythraceae; KT358807). Cells in the heatmap corresponding to $95 \%$ ANIm sequence identity are in red color; Cells corresponding to $75 \%$ ANIm sequence identity are in blue. Color intensity fades as the comparisons approach $95 \%$ ANIm sequence identity. Color bars above and to the left of the heatmap correspond to the species level that was analyzed.

quence (Figure 4). When the phylogenetic analysis was performed using the atpA, rpoC2, pcbE, $n d h H$, and $r p s 16$ genes (Figure S3), i.e., excluding the $y c f 2$ gene sequence, Syzygieae was positioned basal to Myrteae and Eucalypteae, differing from the trees built using all six genes (Figure S2) and based only on the $y c f 2$ sequence (Figure 4). However, the support for the node of Myrteae in this tree was low $(\mathrm{PP}=0.55$; Figure $\mathrm{S} 3)$.

\section{Discussion}

\section{Structural patterns of the C. xanthocarpa plastome in comparison to other Myrtaceae}

Conservation of plastome structure has been reported for species of Myrtaceae concerning the total length, as well as the length of the SSC, LSC and IR regions, and the number and position of genes (Machado et al., 2017, Xiao-Ming et al., 2017). Fitting with these previous findings, the assem- bly and annotation of the C. xanthocarpa plastome revealed a general structure, including number and category of the genes, similar to that of other 47 species of Myrtaceae, suggesting overall stability. The reduction of the C. xanthocarpa plastome is not related to a loss of genes or pseudogenes. Large expansions and reductions in plastome sizes in higher plants have been attributed to the extension of inverted repeats into neighboring single copy regions (Ravi et al., 2008). The difference between the C. xanthocarpa plastome and the plastomes of the other species included in this study, which ranged from 314 bp (in comparison to $E$. uniflora) to $2,940 \mathrm{bp}$ (in comparison to E. spathulata), was due to indels occurring in intergenic regions of both, IR and LSC regions of all species, except for $P$. dioica (Table 1).

While the structure of the C. xanthocarpa plastome presented such stability, the analysis of the $y c f 2$ gene suggested the occurrence of different patterns of selection at family and at tribe levels. In this study, we found very low 


\begin{tabular}{|c|c|c|c|c|}
\hline & $\begin{array}{c}2277 \\
\cdot \mid .\end{array}$ & & $\begin{array}{c}2292 \\
. \quad 1 .\end{array}$ & \\
\hline Campomanesia xanthocarpa & MTKTLLRKRWL F P D MVVA I C S I & & & \\
\hline Acca sellowiana & MTKT L L R KRWL F P D E MK I G F M * & - & - - & \\
\hline Allosyncarpia ternata & MTK T L L R KRWL F P D EMK I G F M * & - & - & \\
\hline Angophora costata & MT K T L L R KRWL F P D EMK I G F M * & & - & \\
\hline Angophora floribunda & MT K T L L R KR WL F P D E MK I G F M * & - & - & - - \\
\hline Corymbia eximia & MT K T L L R KRWL F P D E MK I G F M * & & - & -- \\
\hline Corymbia gummifera & MTKT L L R KRWL F P D E MK I G F M * & - & - & \\
\hline Corymbia henryi & MTKT L L R KRWL F P D EMK I G F M * & - & - & -- \\
\hline Corymbia maculata & MT K T L L R KRWL F P D E MK I G F M * & - & - & $-\cdots$ \\
\hline Corymbia tessellaris & MTK T L L R KRWL F P D E MK I G F M * & & - & -- \\
\hline Corymbia torelliana & MT K T L L R KRWL F P D EMK I G F M * & & - & \\
\hline Eucalyptus aromaphloia & MT K T L L R KRWL F P D E MK I G F M * & - & - & - \\
\hline Eucalyptus baxteri & MT K T L L R KRWL F P D E MK I G F M * & - & - & -- \\
\hline Eucalyptus camaldulensis & MT K T L L R KRWL F P D E MK I G F M * & & - & \\
\hline Eucalyptus cladocalyx & MTK T L L R KRWL F P D E MK I G F M * & - & -- & $-\cdots$ \\
\hline Eucalyptus cloeziana & MT K T L L R KRWL F P D E MK I G F M * & - & - & -- \\
\hline Euc & MTKT L L R KRWL F P D E MK I G F M * & & -- & - - \\
\hline Euc & MTK T L L R KRWL F P D E MK I G F M * & - & -- & -- \\
\hline ensis & MTK T L L R KRWL F P D E MK I G F M * & - & - & - \\
\hline Euc & MTK T L L R KRWL F P D E MK I G F M * & - & - & - - \\
\hline Euc: & MT K T L L R KRWL F P D E MK I G F M * & - & - & -- \\
\hline Euc: & MTK T L L R KRWL F P D E MK I G F M * & - & -- & - \\
\hline Euc & MTK T L L R KRWL F P D EMK I G F M * & - & & -- \\
\hline Euca & MTKT L L R KRWL F P D EMK I G F * & -- & & 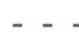 \\
\hline Euc: & MTK T L L R KRWL F P D EMK I G F M * & -- & -- & - \\
\hline Euc & MTK T L L R KRWL F P D E MK I G F M * & - & & -- \\
\hline Euc & MTK T L L R KRWL F P D EMK I G F M * & - & & \\
\hline Euc & MTK T L L R KRWL F P D EMK I G F M * & - - & -- & - \\
\hline Euc & MTK T L L R KRWL F P D EMK I G F M * & - & & -- \\
\hline Euc & MTK T L L R KRWL F P D EMK I G F M * & - & & \\
\hline Euc & MTK T L L R KRWL F P D EMK I G F M * & -- & -- & -- \\
\hline Euc & MTKTLLRKRWL F P D EMK I G FM * & - & -- & - \\
\hline Euc & MTK T L L R KRWL F P D EMK I G F M * & - & & -- \\
\hline Euc & MTK T L L R KRWL F P D EMK I G F M * & -- & & \\
\hline Euc & MTK T L L R KRWL F P D EMK I G F M * & - & -- & - \\
\hline Euc & MTK T L L R KRWL F P D EMK I G F M * & - & - & -- \\
\hline Euc & MTK T L L R KRWL F P D EMK I G F M * & & & \\
\hline Euc & MTK T L L R KRWL F P D EMK I G F M * & - & -- & -- \\
\hline Euc & MTKTLLRKRWL F P D EMK I G F I V I & $\mathbf{E} \mathbf{R}$ & & I T \\
\hline Euc & MTK T L L R KRWL F P D EMK I G F M * & -- & -- & -- \\
\hline Euc: & MTK T L L R KRWL F P D EMK I G FM * & - & - & . \\
\hline Eucalyptus & MTK T L L R KRWL F P E MK I G F M * & - & -- & -- \\
\hline Eug & MTK T L L R KRWL F P D EMK I G F M * & - & - & -- \\
\hline adrifida & MTK T L L R KRWL F P D EMK I G F M * & & & \\
\hline Syzygium cumini & MTKT L L R KRWL F P D EMK I G F M * & - & - & -- \\
\hline Pimenta dioica & M T K T L L R KRWL F P D E MK I G F M * & & - & -- \\
\hline & MTK T L L R KRWL F T D EMK I G F M * & & - & \\
\hline Psidium guajava & MTK T L L R KRWL F P D EMK I G FME & & & \\
\hline
\end{tabular}

Figure 3 - Comparison of the C-terminal region of the amino acid sequences of the $y c f 2$ gene in 47 species of Myrtaceae.

variability in this gene among published plastomes of Myrtaceae species, with 45 species presenting the same length and same amino acid sequences for the $y c f 2$ gene. However, the $y c f 2$ gene of $C$. xanthocarpa is $18 \mathrm{bp}$ longer than those of these species, 15 bp longer than that of Psidium guajava and has the same size as that of Eucalyptus spathulata. Moreover, having the same amino acid sequences does not mean having the same nucleotide sequences, what enables the exploitation of the nucleotide sequences of the $y c f 2$ gene as a barcode region in plants (Kumar et al., 2009). The ycf2 gene has an essential, but yet little known function in higher plants. Kikuchi et al. (2018) demonstrated the function of a protein encoded by this gene, associated to five related nuclear-encoded FtsH-like proteins, in the translocation of preproteins across the inner membrane of the chloroplast. Silencing or reduction in the mRNA synthesis of this gene has been shown to induce cell apoptosis (Drescher et al., 2000). It seems, however, that the elongation of this gene 
Table 4 - Comparison of polymorphisms (segregating sites), nonsynonymous $(K a)$ and synonymous $(K s)$ substitution rates and $K a / K s$ ratio of the $y c f 2$ gene among Campomanesia xanthocarpa and 46 species of Myrtaceae.

\begin{tabular}{|c|c|c|c|c|}
\hline \multirow[t]{2}{*}{ Species } & \multicolumn{4}{|c|}{ C. xanthocarpa/Species } \\
\hline & Polymorphisms & $K a$ & Ks & $K a / K s$ \\
\hline \multicolumn{5}{|l|}{ Tribe Myrteae } \\
\hline Acca sellowiana & 13 & 0.0021 & 0.0010 & 2.0114 \\
\hline Eugenia uniflora & 15 & 0.0021 & 0.0028 & 0.7413 \\
\hline Pimenta dioica & 13 & 0.0019 & 0.0020 & 0.9677 \\
\hline Plinia trunciflora & 19 & 0.0032 & 0.0010 & 3.0000 \\
\hline Psidium guajava & 26 & 0.0035 & 0.0049 & 0.7127 \\
\hline \multicolumn{5}{|l|}{ Tribe Eucalypteae } \\
\hline Corymbia eximia & 40 & 0.0046 & 0.0118 & 0.3921 \\
\hline Corymbia gummifera & 42 & 0.0054 & 0.0101 & 0.5314 \\
\hline Corymbia henryi & 42 & 0.0051 & 0.0110 & 0.4677 \\
\hline Corymbia maculata & 42 & 0.0051 & 0.0110 & 0.4677 \\
\hline Corymbia tessellaris & 43 & 0.0052 & 0.0117 & 0.4420 \\
\hline Corymbia torelliana & 44 & 0.0052 & 0.0127 & 0.4053 \\
\hline Eucalyptus aromaphloia & 42 & 0.0050 & 0.0116 & 0.4309 \\
\hline Eucalyptus baxteri & 40 & 0.0046 & 0.0118 & 0.3921 \\
\hline Eucalyptus camaldulensis & 43 & 0.0052 & 0.0117 & 0.4433 \\
\hline Eucalyptus cladocalyx & 44 & 0.0052 & 0.0127 & 0.4062 \\
\hline Eucalyptus cloeziana & 40 & 0.0046 & 0.0118 & 0.3921 \\
\hline Eucalyptus curtisii & 44 & 0.0053 & 0.0121 & 0.4403 \\
\hline Eucalyptus deglupta & 44 & 0.0054 & 0.0115 & 0.4704 \\
\hline Eucalyptus delegatensis & 41 & 0.0048 & 0.0119 & 0.4043 \\
\hline Eucalyptus diversicolor & 44 & 0.0052 & 0.0124 & 0.4199 \\
\hline Eucalyptus diversifolia & 41 & 0.0048 & 0.0116 & 0.4189 \\
\hline Eucalyptus elata & 40 & 0.0046 & 0.0118 & 0.3921 \\
\hline Eucalyptus erythrocorys & 46 & 0.0053 & 0.0138 & 0.3811 \\
\hline Eucalyptus globulus & 43 & 0.0052 & 0.0114 & 0.4584 \\
\hline Eucalyptus grandis & 45 & 0.0054 & 0.0125 & 0.4318 \\
\hline Eucalyptus guilfoylei & 41 & 0.0048 & 0.0119 & 0.4038 \\
\hline Eucalyptus marginata & 42 & 0.0050 & 0.0117 & 0.4302 \\
\hline Eucalyptus melliodora & 45 & 0.0053 & 0.0128 & 0.4173 \\
\hline Eucalyptus microcorys & 39 & 0.0044 & 0.0121 & 0.3655 \\
\hline Eucalyptus nitens & 42 & 0.0050 & 0.0116 & 0.4309 \\
\hline Eucalyptus obliqua & 41 & 0.0048 & 0.0119 & 0.4043 \\
\hline Eucalyptus patens & 39 & 0.0046 & 0.0108 & 0.4304 \\
\hline Eucalyptus polybractea & 44 & 0.0052 & 0.0127 & 0.4062 \\
\hline Eucalyptus radiata & 41 & 0.0048 & 0.0119 & 0.4043 \\
\hline Eucalyptus regnans & 41 & 0.0046 & 0.0128 & 0.3594 \\
\hline Eucalyptus saligna & 42 & 0.0051 & 0.0119 & 0.4283 \\
\hline Eucalyptus salmonophloia & 44 & 0.0050 & 0.0136 & 0.3641 \\
\hline Eucalyptus sieberi & 41 & 0.0046 & 0.0128 & 0.3591 \\
\hline Eucalyptus spathulata & 44 & 0.0053 & 0.0121 & 0.4362 \\
\hline Eucalyptus torquata & 43 & 0.0052 & 0.0117 & 0.4429 \\
\hline Eucalyptus umbra & 42 & 0.0050 & 0.0120 & 0.4162 \\
\hline Eucalyptus verrucata & 41 & 0.0048 & 0.0116 & 0.4186 \\
\hline Stockwellia quadrifida & 34 & 0.0037 & 0.0115 & 0.3207 \\
\hline \multicolumn{5}{|l|}{ Tribe Syzygieae } \\
\hline Syzygium cumini & 35 & 0.0043 & 0.0093 & 0.4587 \\
\hline
\end{tabular}




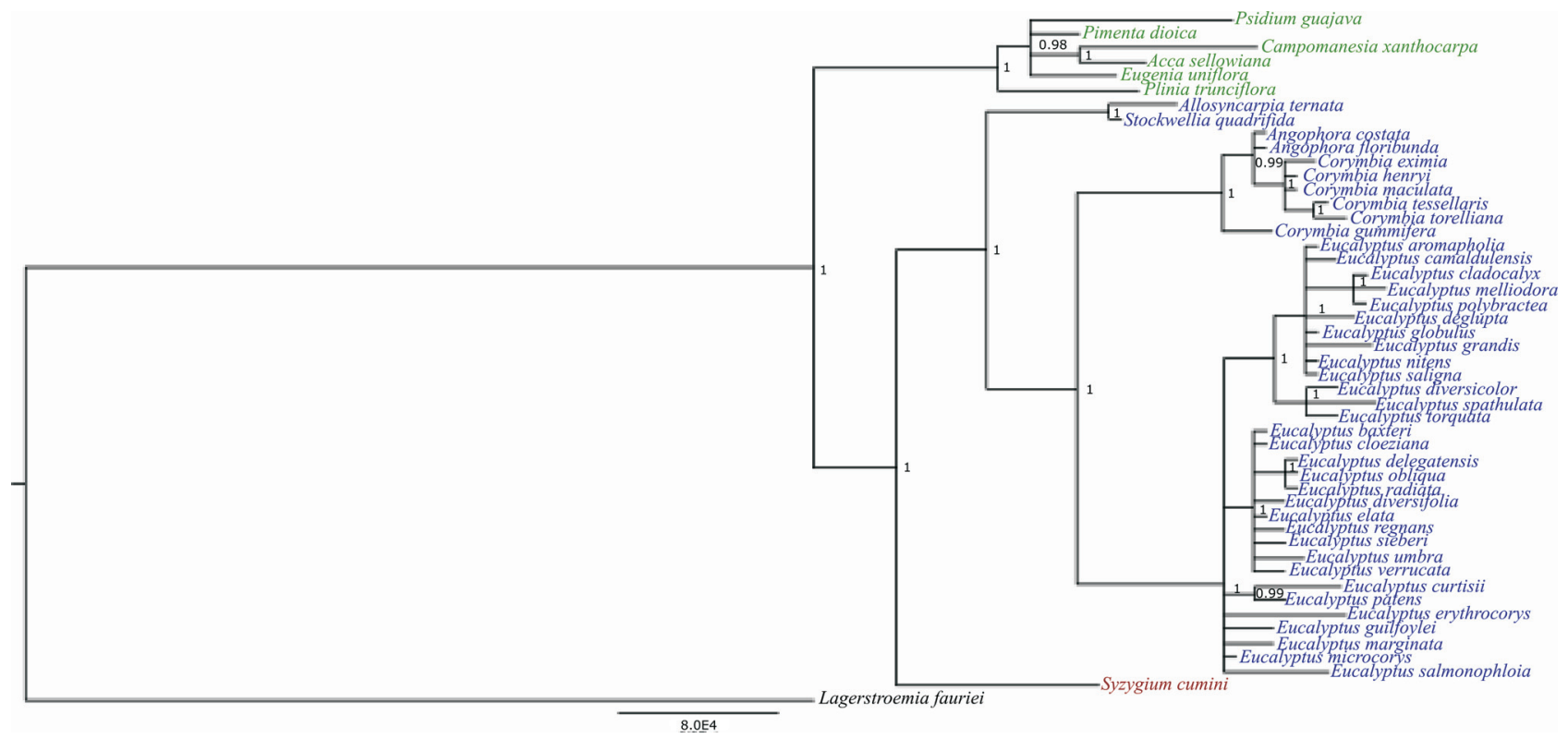

Figure 4 - Bayesian phylogeny based on the cp ycf2 sequence of 48 Myrtaceae species and the outgroup species Lagerstroemia fauriei (Myrtales: Lythraceae; KT358807). Branch length is proportional to the inferred divergence level. The scale bar indicates the number of inferred nucleic acid substitutions per site.

and the substitution of some amino acids in the C-terminal portion of the sequence has no deleterious effect in $C$. xanthocarpa, $P$. guajava and E. spathulata.

\section{Modest signatures of positive selection for the $C$. xanthocarpa ycf2 gene within Myrtaceae}

Increased substitution rates and elevated $\mathrm{Ka} / \mathrm{Ks}$ ratios for similar sets of plastid genes have been reported for several plant species. However, it remains uncertain whether these patterns reflect positive selection, relaxed purifying selection, changes in underlying mutation rates, a breakdown in DNA repair mechanisms, such as gene conversion, or some combination of these (Barnard-Kubow et al., 2014).

Concerning the evolutionary patterns of the $y c f 2$ gene of C. xanthocarpa within Myrtaceae, the results of the present study showed evidence of purifying selection acting over this region. The number of segregating sites, not surprisingly, revealed the higher polymorphism when comparing C. xanthocarpa to species of tribe Eucalypteae and Syzygieae. For the species of tribe Myrteae, the highest polymorphism was observed between $C$. xanthocarpa and P. guaja$v a$, supporting the phylogenetic relationship recovered by the $y c f 2$ gene alone, and also using the six plastid genes with high diversity (Figure 4).

In relation to tribe Eucalypteae and Syzygieae $(\mathrm{Ka} / \mathrm{Ks}$ ratios $<0.5314$ ), the pattern of purifying selection is more evident, towards equilibrium in relation to other species from the Myrteae tribe $(K a / K s$ ratio > 0.7127). Machado et al. (2017) observed a $K a / K s$ ratio of 0.30 for this gene by comparing the plastomes of the close-related Myrtaceae species $A$. sellowiana and E. uniflora, evidencing purifying selection. Evidence of relaxed purifying selection over the $y c f 2$ gene was also reported for Campanulastrum americanum
(Campanulaceae) by Barnard-Kubow et al. (2014). However, the estimated $\mathrm{Ka} / \mathrm{Ks}$ ratio is a mean over the full length of the gene and, considering its very large size, some regions of $y c f 2$ are likely experiencing stronger selection, while other regions are more conserved. This hypothesis has to be closely tested, but the sliding window analysis of Tajima's $D$ estimations (data not shown) revealed such a pattern of gene regions with significant $(p<0.05)$ negative values within $y c f 2$, suggesting signatures of positive selection.

\section{Taxonomic and phylogenetic patterns of Myrtaceae as revealed by whole plastome and the ycf2 gene}

The taxonomic patterns within Myrtaceae revealed by the analysis of the whole plastome sequences clearly clustered species at the tribe level, with ANI $>95 \%$. Studies involving prokaryotic organisms with ANI values $>95 \%$ indicate that they belong to the same species (Goris et al., 2007; Richter and Rossello-Mora, 2009). In our study, we applied the ANI to investigate the identity level of the whole plastome among Myrtaceae species. This is the first time such an analysis was performed for organellar genomes, and it seems to be a useful approach, since the obtained outcomes fit the results obtained using classical phylogenetic analyses based on plastidial genes.

Similarly, the Bayesian phylogenetic inference using the plastidial $y c f 2$ gene confirmed the monophyly of the tribes Myrteae, Eucalypteae and Sysygieae, as already suggested through phylogenetic inferences based on plastidial and nuclear genes (Sytsma et al., 2004; Wilson et al., 2005; Biffin et al., 2010; Thornhill et al., 2012, 2015), as well as through combined analysis of plastidial DNA regions ( $m a t K$ and $n d h F$ ) (Biffin et al., 2010), 78 protein-coding and four rRNA genes (Jo et al., 2016), 57 plastidial protein-coding 

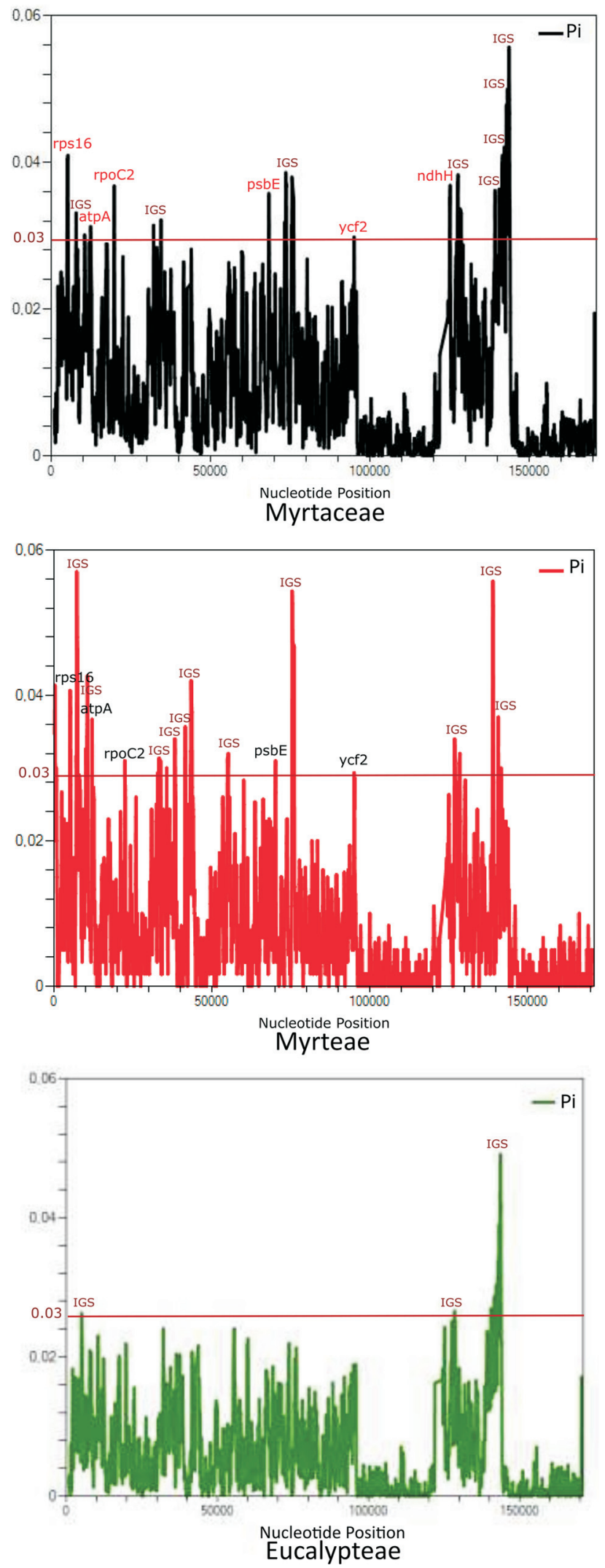

Figure 5 - Sliding window analyses of aligned whole plastomes for the family Myrtaceae, the tribe Myrteae and the tribe Eucalypteae. The regions with high nucleotide variability $(\mathrm{Pi}>0.03)$ are indicated. $\mathrm{Pi}=$ nucleotide diversity within each window. genes (Huang et al., 2013; Eguiluz et al., 2017), and complete plastidial sequences (Machado et al., 2017). Also, the topology of the tribe Eucalypteae is equivalent to that proposed based on plastidial genomes (Bayly et al., 2013, 2016) and on nuclear ribosomal ITS sequences (Parra-O et al., 2006). The $y c f 2$ gene was one of the six genes with higher polymorphism at family and at tribe levels (Figure 5), corroborating the potential of this plastid region for specieslevel DNA barcoding, as proposed by Kumar et al. (2009).

The internal topology of the tribe Myrteae phylogeny obtained with the $y c f 2$ gene needs to be evaluated with caution, because it is the most species-rich tribe within Myrtaceae (Thornhill et al., 2015), and we have the $y c f 2$ sequence from just six species representing this taxon. At a higher level, the phylogeny presented by Lucas et al. (2007), based on ITS, ETS, psbA-trnH and matK sequences places the Pimenta group as sister of the Eugenia group, while the Plinia group is placed externally to these two groups. In the $y c f 2$ phylogeny, the species from Pimenta (Acca sellowiana, Campomanesia xanthocarpa, Psidium guajava and Pimenta dioica) and Eugenia (Eugenia uniflora) groups were not separated, and Plinia trunciflora was placed externally, as in the phylogeny presented by Lucas et al. (2007).

\section{The shortest plastome and longest gene within Myrtaceae}

Addressing three main questions in this study concerning the structure and evolution of the plastome of C. xanthocarpa, we highlighted some relevant features. First, although the plastome of $C$. xanthocarpa conserves the same general structure as in other 47 studied species, regarding number and position of genes, it is the shortest recorded plastidial genome within the family.

Second, the $y c f 2$ gene of C. xanthocarpa is the longest among the Myrtaceae species that had sequences of this gene deposited in GenBank at the time of this study. Signatures of moderate purifying selection were observed for the $y c f 2$ gene of $C$. xanthocarpa within Myrtaceae, more apparent in relation to tribe Eucalypteae and tending to equilibrium relative to tribe Myrteae. In addition, the $y c f 2$ gene revealed a robust phylogenetic signal at the family level, generating a Bayesian inference of phylogenetic relationships equivalent to the taxonomic classification presented using the whole plastome sequences and average nucleotide identity analysis.

Although in the starting steps, these findings have important implications for thinking about the genetics, evolution, conservation, breeding, and biotechnology of C. xanthocarpa, a fruit tree species with high biotechnological and agricultural potential that is still underexploited. Understanding the evolutionary and taxonomic/phylogenetic relationships of this species relative to other species from Myrtaceae enables the elaboration of conservation, breeding and biotechnology programs with a consistent scientific basis. Thus, enterprises towards safeguarding and managing the species' genetic resources, as well as selecting and developing cultivars for agricultural or biotechnological uses will be greatly 
benefited by the results of this study. For instance, plastid SSR markers for $C$. xanthocarpa will be soon released by our group, with direct applicability for marker assisted selection.

\section{Acknowledgments}

This work was funded by the Fundação de Amparo à Pesquisa e Inovação do Estado de Santa Catarina (FAPESC Projects 14848/2011-2 and 2780/2012-4). We also thank the Coordenação de Aperfeiçoamento de Pessoal de Nível Superior (CAPES) - (Finance code 001) for scholarships to LOM, and the Conselho Nacional de Desenvolvimento Científico e Tecnológico (CNPq) for fellowships to VMS, LNV, MPG, FOP and RON.

\section{Conflict of Interest}

The authors declare that they have no conflict of interest.

\section{Author Contributions}

VMS and RON conceived of the presented idea and design the experimental work. LOM carried out the experiments. HF and FOP did the sequencing work. LOM, LNV, VMS and HF performed the acquisition of data and the bioinformatic and statistical analysis. LOM and RON elaborated the first draft. VMS elaborated the second draft. All authors revised the second draft to produce the submitted manuscript and give final approval to submitted and revised versions.

\section{References}

Asano TT, Tsudzuki S, Takahashi H, Shimada and Kadowaki K (2004) Complete nucleotide sequence of the sugarcane (Saccharum officinarum) chloroplast genome: a comparative analysis of four monocot chloroplast genomes. DNA Res 11:93-99.

Auharek SA, Vieira MC, Cardoso CAL, Oliveira RJ and CunhaLaura AL (2013) Reproductive toxicity of Campomanesia xanthocarpa (Berg.) in female Wistar rats. J Ethnopharmacol 148:341-343.

Barnard-Kubow KB, Sloan DB and Galloway LF (2014) Correlation between sequence divergence and polymorphism reveals similar evolutionary mechanisms acting across multiple timescales in a rapidly evolving plastid genome. BMC Evol Biol $14: 1$.

Bayly MJ, Rigault P, Spokevicius A, Ladiges PY, Ades PK, Anderson C, Bossinger G, Merchant A, Udovicic F, Woodrow IE et al. (2013) Chloroplast genome analysis of Australian eucalypts - Eucalyptus, Corymbia, Angophora, Allosyncarpia and Stockwellia (Myrtaceae). Mol Phylogenet Evol 69:704-716.

Bayly MJ (2016) Phylogenetic studies of eucalypts: Fossils, morphology and genomes. Proc R Soc Victoria 128:12-24.

Biavatti MW, Farias C, Curtius F, Brasil LM, Hort S, Schuster L, Leite SN and Prado SRT (2004) Preliminary studies on Campomanesia xanthocarpa (Berg.) and Cuphea carthagenensis (Jacq.) J.F. Macbr. aqueous extract: weight control and biochemical parameters. J Ethnopharmacol 93:385-389.
Biffin E, Lucas EJ, Craven LA, Da Costa IR, Harrington MG and Crisp MD (2010) Evolution of exceptional species richness among lineages of fleshy-fruited Myrtaceae. Ann Bot 106:79-93.

Bock R (2007) Structure, function, and inheritance of plastid genomes. Cell Mol Biol Plast 19:29-63.

Capeletto C, Conterato G, Scapinello J, Rodrigues FS, Copini MS, Kuhn F, Tres MV, Magro JD and Oliveira JV (2016) Chemical composition, antioxidant and antimicrobial activity of guavirova (Campomanesia xanthocarpa Berg) seeds extracts obtained by supercritical CO2 and compressed n-butane. J Supercrit Fluid 110:32-38.

Darriba D, Taboada GL, Doallo R and Posada D (2012) jModelTest 2: More models, new heuristics and parallel computing. Nat Methods 9:772-772.

Downie SR, Katz-Downie DS, Wolfe KH, Calie PJ and Palmer JD (1994) Structure and evolution of the largest chloroplast gene (ORF2280): Internal plasticity and multiple gene loss during angiosperm evolution. Curr Genet 25:367-378.

Drescher A, Ruf S, Calsa Jr T, Carrer H and Bock R (2000) The two largest chloroplast genome-encoded open reading frames of higher plants are essential genes. Plant J 22:97-104.

Edgar RC (2004) MUSCLE: A multiple sequence alignment method with reduced time and space complexity. BMC Bioinformatics 5:113.

Eguiluz M, Rodrigues NF, Guzman F, Yuyama P and Margis R (2017) The chloroplast genome sequence from Eugenia uniflora, a Myrtaceae from Neotropics. Plant Syst Evol 303:1199-1212.

Glick RE and Sears BB (1993) Large unidentified open reading frame in plastid DNA (ORF2280) is expressed in chloroplasts. Plant Mol Biol 21:99-108.

Goris J, Konstantinidis KT, Klappenbach JA, Coenye T, Vandamme P and Tiedje JM (2007) DNA - DNA hybridization values and their relationship to whole-genome sequence similarities. Int J Syst Evol Microbiol 57:81-91.

Grattapaglia D, Vaillancourt RE, Shepherd M, Thumma BL, Foley W, Külheim C, Potts B and Myburg A (2012) Tree Genet Genomes 8:463-508.

Huang JL, Sun GL and Zhang DM (2010) Molecular evolution and phylogeny of the angiosperm $y c f 2$ gene. J Syst Evol 48:240-248.

Huang YY, Matzke AJM and Matzke M (2013) Complete sequence and comparative analysis of the chloroplast genome of coconut. PLoS One 876:871-876.

Jo S, Kim HW, Kim YK, Cheon SH and Kim KJ (2016) Complete plastome sequence of Psidium guajava L. (Myrtaceae). Mitochondrial DNA B Resour 1:612-614.

Katoh K and Standley DM (2013) MAFFT multiple sequence alignment software version 7: Improvements in performance and usability. Mol Biol Evol 30:772-780.

Kikuchi S, Asakura Y, Imai M, Nakahira Y, Kotani Y, Hashiguchi Y, Nakai Y, Takafuji K, Bédard J and Hirabayashi-Ishioka Y (2018) A Ycf2-FtsHi heteromeric AAA-ATPase complex is required for chloroplast protein import. Plant Cell 30:2677-2703.

Klafke JZ, Silva MA, Panigas TF, Belli KC, Oliveira MF, Barichello MM, Rigo FK, Rossato MF, Santos ARS, Pizzolatti MG et al. (2010) Effects of Campomanesia xanthocarpaon biochemical, hematological and oxidative stress parameters in hypercholesterolemic patients. J Ethnopharmacol 127:299-305.

Klafke JZ, Pereira RLD, Hirsch GE, Parisi MM, Porto FG, Almeida AS, Rubin FH, Schmidt A, Beutler H, Nascimento S et al. 
(2016) Study of oxidative and inflammatory parameters in LDLr-KO mice treated with a hypercholesterolemic diet: Comparison between the use of Campomanesia xanthocarpa and acetylsalicylic acid. Phytomedicine 23:1227-1234.

Kumar S, Hahn FM, McMahan CM, Cornish K and Whalen MC (2009) Comparative analysis of the complete sequence of the plastid genome of Parthenium argentatum and identification of DNA barcodes to differentiate Parthenium species and lines. BMC Plant Biol 9:131.

Kurtz S and Schleiermacher C (1999) REPuter: Fast computation of maximal repeats in complete genomes. Bioinformatics 15:426-427.

Librado P and Rozas J (2009) DnaSP v5: A software for comprehensive analysis of DNA polymorphism data. Bioinformatics 25:1451-1452.

Lohse M, Drechsel O and Bock R (2007) OrganellarGenomeDRAW (OGDRAW): A tool for the easy generation of high-quality custom graphical maps of plastid and mitochondrial genomes. Curr. Genet 52:267-274.

Lopes AS, Pacheco TG, Nimz T, Vieira LN, Guerra MP, Nodari RO, Souza EM, Pedrosa FO and Rogalski M (2018a) The complete plastome of macaw palm [Acrocomia aculeata (Jacq.) Lodd. ex Mart.] and extensive molecular analyses of the evolution of plastid genes in Arecaceae. Planta 247:1011-1030.

Lopes AS, Pacheco TG, Nimz T, Vieira LN, Guerra MP, Nodari RO, Souza EM, Pedrosa FO and Rogalski M (2018b) The Linum usitatissimum L. plastome reveals atypical structural evolution, new editing sites, and the phylogenetic position of Linaceae within Malpighiales. Plant Cell Rep 37:307-328.

Lorenzi H (1992) Árvores brasileiras: manual de identificação e cultivo de plantas arbóreas nativas do Brasil. Editora Plantarum, Nova Odessa, $352 \mathrm{p}$.

Lucas EJ, Harris SA, Mazine FF, Belsham SR, Niclughada EM, Telford A, Gasson PE, Mark W and Chase MW (2007) Supragenericphylogenetics of Myrteae, the generically richest tribe in Myrtaceae (Myrtales). Taxon 56:1105-1128.

Machado LO, Vieira LN, Stefenon VM, Pedrosa FO, Souza EM, Guerra MP and Nodari RO (2017) Phylogenomic relationship of feijoa (Acca sellowiana (O.Berg) Burret) with other Myrtaceae based on complete chloroplast genome sequences. Genetica 145:163-174.

Maier RM, Neckermann K, Igloi GL and Ko H (1995) Complete sequence of the maize chloroplast genome: Gene content, hotspots of divergence and fine tuning of genetic information by transcript editing. J Mol Biol 251:614-628.

Matsuoka Y, Yamazaki Y, Ogihara Y and Tsunewaki K (2002) Whole chloroplast genome comparison of rice, maize, and wheat: Implications for chloroplast gene diversification and phylogeny of cereals. Mol Biol Evol 19:2084-2091.

Markman BEO, Bacchi EM and Kato ETM (2004) Antiulcerogenic effects of Campomanesia xanthocarpa J Ethnopharmacol 94:55-57.

Millen RS, Olmstead RG, Adams KL, Palmer JD, Lao NT, Heggie L, Kavanagh TA, Hibberd JM, Gray JC, Morden CW et al. (2001) Many parallel losses of infA from chloroplast DNA during angiosperm evolution with multiple independent transfers to the nucleus. Plant Cell 13:645-658.

Oliver MJ, Murdock AG, Mishler BD, Kuehl JV, Boore JL, Mandoli DF, Everett KDE, Wolf PG, Duffy AM and Karol KG (2010) Chloroplast genome sequence of the moss Tortula ruralis: Gene content, polymorphism, and structural arrangement relative to other green plant chloroplast genomes. BMC Genomics 11:143.
Parra-O C, Bayly M, Udovicic F and Ladiges P (2006) ETS sequences support the monophyly of the eucalypt genus Corymbia (Myrtaceae). Taxon 55:653-663.

Ravi V, Khurana JP, Tyagi AK and Khurana P (2008) An update on chloroplast genomes. Plant Syst Evol 271:101.

Richter M and Rossello-Mora R (2009) Shifting the genomic gold standard for the prokaryotic species definition. Proc Natl Acad Sci U S A 106:19126-19131.

Schattner P, Brooks AN and Lowe TM (2005) The tRNAscan-SE, snoscan and snoGPS web servers for the detection of tRNAs and snoRNAs. Nucleic Acids Res 33: 686-689.

Souza VC and Lorenzi H (2005) Botânica sistemática: guia ilustrado para identificação das famílias de Angiospermas da flora brasileira, baseado em APG II. Instituto Plantarum, Nova Odessa, $640 \mathrm{p}$.

Steane DA (2005) Complete nucleotide sequence of the chloroplast genome from the Tasmanian blue gum, Eucalyptus globulus (Myrtaceae). DNA Res 12:215-220.

Sytsma KJ, Litt A, Zjhra ML, Pires JC, Nepokroeff M, Conti E, Walker J and Wilson PG (2004) Clades, clocks, and continents: historical and biogeographical analysis of Myrtaceae, Vochysiaceae, and relatives in the Southern Hemisphere source Int J Plant Sci 165:S85-S105.

Thornhill AH, Popple LW, Carter RJ, Ho SYW and Crisp MD (2012) Are pollen fossils useful for calibrating relaxed molecular clock dating of phylogenies? A comparative study using Myrtaceae. Mol Phylogenet Evol 63:15-27.

Thornhill AH, Ho SYW, Külheim C and Crisp MD (2015) Interpreting the modern distribution of Myrtaceae using a dated molecular phylogeny. Mol Phylogenet Evol 93:29-43.

Viecili PR, Borges DO, Kirsten K, Malheiros J, Viecili E, Melo RD, Trevisan G, Silva MA, Bochi GV, Moresco RN et al. (2014) Effects of Campomanesia xanthocarpa on inflammatory processes, oxidative stress, endothelial dysfunction and lipid biomarkers in hypercholesterolemic individuals. Atherosclerosis 234:85-92.

Vieira LN, Faoro H, Fraga HPF, Rogalski M, Souza EM, Pedrosa FO, Nodari RO and Guerra MP (2014a) An improved protocol for intact chloroplasts and cpDNA isolation in conifers. PLoS One 9:e84792.

Vieira LN, Faoro H, Rogalski M, Fraga HPF, Cardoso RLA, Souza EM, Pedrosa FO, Nodari RO and Guerra MP (2014b) The complete chloroplast genome sequence of Podocarpus lambertii: genome structure, evolutionary aspects, gene content and SSR detection. PLoS One 9:e90618.

Vieira LN, Rogalski M, Faoro H, Fraga HPF, Goulart KA, Picchi GFA, Nodari RO, Pedrosa FO, Souza EM and Guerra MP (2016a) The plastome sequence of the endemic Amazonian conifer, Retrophyllum piresii (Silba) C.N.Page, reveals different recombination events and plastome isoforms. Tree Genet Genomes 12:10.

Vieira LN, Goulart KA, Faoro H, Fraga HPF, Greco TM, Pedrosa FO, Souza EM, Rogalski M, Souza RF and Guerra MP (2016 b) Phylogenetic inference and SSR characterization of tropical woody bamboos tribe Bambuseae (Poaceae: Bambusoideae) based on complete plastid genome sequences. Curr Genet 62:443-453.

Wilson PG, O'Brien MM, Heslewood MM and Quinn CJ (2005) Relationships within Myrtaceae sensu lato based on a matK phylogeny. Plant Syst Evol 251:3-19.

Wolf PG, Der JP, Duffy AM, Davidson JB, Grusz AL and Pryer KM (2011) The evolution of chloroplast genes and genomes in ferns. Plant Mol Biol 76:251-261. 
Wolfe KH (1994) Similarity between putative ATP-binding sites in land plant plastid ORF2280 proteins and the FtsH/CDC48 family of ATPases. Curr Genet 25:379-383.

Wyman SK, Jansen RK and Boore JL (2004) Automatic annotation of organellar genomes with DOGMA. Bioinformatics 20:3252-3255.

Xiao-Ming Z, Junrui W, Li F, Liu S, Pang H, Qi L, Li J, Sun Y, Qiao $\mathrm{W}$, Zhang L et al. (2017) Inferring the evolutionary mechanism of the chloroplast genome size by comparing wholechloroplast genome sequences in seed plants. Sci Rep 7:1555.

Zhang Z, Li J, Zhao XQ, Wang J, Wong GKS and Yu J (2006) KaKs_Calculator: calculating $\mathrm{Ka}$ and $\mathrm{Ks}$ through model selection and model averaging. Genomics Proteomics Bioinformatics 4:259-263.

\section{Internet Resources}

The Plant List (2013) Version 1.1, http://www.theplantlist.org/ (accessed 08 April 2019).

\section{Supplementary material}

The following supplementary material is available for this article:

Figure S1 - Comparison of boundary positions between single copy and inverted repeat regions among 13 chloroplast genomes of Myrtales.

Figure S2 - Bayesian phylogeny based on six most variable genes on chloroplast sequences of 48 Myrtaceae species and the outgroup Lagerstroemia fauriei (Myrtales: Lythraceae; KT358807).

Figure S3 - Bayesian phylogeny based on five most variable genes on chloroplast sequences of 48 Myrtaceae species and the outgroup Lagerstroemia fauriei (Myrtales: Lythraceae; KT358807).

Table S1- List of genes identified in Campomanesia xanthocarpa chloroplast genome.

Associate Editor: Guilherme Corrêa de Oliveira

License information: This is an open-access article distributed under the terms of the Creative Commons Attribution License (type CC-BY), which permits unrestricted use, distribution and reproduction in any medium, provided the original article is properly cited. 